\title{
THE ROLE OF BERRIES IN QUALITY AND SAFETY ENSURING OF GOAT'S AND COW'S MILK YOGHURT
}

\author{
Tatiana Cușmenco*, ORCID ID: 0000-0001-6628-0752, \\ Elisaveta Sandulachi, ORCID ID: 0000-0003-3017-9008, \\ Viorica Bulgaru, ORCID ID: 0000-0002-1921-2009, \\ Artur Macari, ORCID ID: 0000-0003-4163-3771

\begin{abstract}
Technical University of Moldova, 168 Stefan cel Mare blvd., Chisinau, Republic of Moldova
*Corresponding author: Tatiana Cușmenco, tatiana.cusmenco@sa.utm.md
\end{abstract}

Received: 06. 27. 2021

Accepted: 08. 25. 2021

\begin{abstract}
The yogurt was obtained from a combination of $50 \%$ goat's milk and $50 \%$ cow's milk with the inclusion of scald fruits of aronia (Aronia melanocarpa), raspberries (Rubus idaeus), strawberry (Fragaria xanassa). Physico-chemical and microbiological indices were determined, according to standard methods, after manufacture and storage, after 1, 5, 10, 15 days. Compared to other samples, yogurt with aronia showed the best values of the dynamics specific to the development of microorganisms: $2.93 .10^{7} \mathrm{cfu} / \mathrm{ml}$; the growth rate of lactic acid bacteria at fermentation $0.95 \mu$; physico-chemical indices: titratable acidity $85 \pm 0.078^{\circ} \mathrm{T}$, pH $4.28 \pm 0.002$, water activity $0.875 \pm 0.025$; total dry matter $18.45 \pm 0.31 \%$, viscosity $2500 \pm$ $0.023 \mathrm{mPa}$ s, ash content $0.89 \pm 0.10 \%$ and the optical density $2.531 \pm 0.054 \mathrm{~nm}$. Yeasts and molds were not detected in any of the samples. From a physico-chemical point of view, in storage, in all fruit yogurt samples the titratable acidity showed increasing values, $\mathrm{pH}$ remaining in the range of permissible values. In storage fruits formed an association to control the microbiological risk and stability of yogurt. Fruit yogurt shows a synergism with Streptococcus thermophilus, Lactobacillus delbrueckii subsp. bulgaricus, Lactococcus lactis subsp lactis biovar diacetilactis. The overall Pearson coefficient $(\mathrm{Pc}=\mathrm{f}(\mathrm{pH}$ and $\mathrm{MC})$ for all fruit yogurt samples is -0.95066 .
\end{abstract}

Keywords: fermentation, growth curve, lactic acid, lactic acid bacteria, metabolic process, microbial counts (MC), starter culture, synergism.

\section{Introduction}

Nutritionists call yogurt a food product that has a high nutritional value, especially due to its low lactose content and high calcium content, as well as positive bioactive effects, due to prebiotic ingredients and probiotic bacteria contained [1].

Yogurt is obtained by lactic acid fermentation of milk under the action of lactic acid bacteria, which has a significant impact on health because in the fermentation process bioactive peptides are released [2]. 
Consumption of yogurt reduces blood cholesterol levels [3], has an antihypertensive and protective effect on the bone system [4]. The balance of lactic acid bacteria contained in yogurt are important in maintaining intestinal health and could help protect against cancer and coronary heart disease [5]. Yogurt has higher antioxidant properties compared to milk, by releasing biopeptides that monitor the hydrolysis of $\alpha$-casein, $\alpha$-lactalbumin and $\beta$ lactoglobulin [6].

The fermentation process helps to break down large organic molecules into simpler ones by the action of microorganisms $[7,8]$ and obtaining a safer yogurt $[9,10]$. The activity of microorganisms plays a significant role in fermentation, showing changes in physicochemical properties [11]. Fermenting microorganisms are the main factors influencing the quality of yogurt [12]. Lactic bacteria are the dominant microbiota, responsible for the beneficial effects of yogurt $[13,14]$.

In order to extend the shelf life of yoghurt [15] and to give it a more pleasant taste [16], various stabilizers, preservatives and synthetic flavors are added to its composition, which often affect human health and inhibit the nutritional properties of yoghurt [17]. The use of berries (aronia, raspberry and strawberry) could be a healthy alternative to replacing synthetic products as preservatives. At the same time, the chemical composition of the fruits $[18,19,20]$ has a direct impact on the quality of the yogurt-finished product $[21,22]$.

Current research has been made in search of a bactericidal substance and the lactic acid production for a potential bio-preservative. The proteins present in milk act as antimicrobial peptides precursors, improving the natural defense capacity by eliminating pathogenic microorganisms. The study demonstrates the possibility of using berries in yogurt as natural preservatives, as they can inhibit the growth of pathogenic bacteria by using biologically active substances as components for decomposition and oxidation reactions.

The aim of the research is to evaluate the physico-chemical and microbiological characteristics of goat's and cow's milk yogurt with berries. In order to achieve the goal, the following objectives were proposed:

1. Research on the physico-chemical indices of yogurt with selected cultures of Lactobacillus lactis and Streptococcus thermophilus during fermentation and during its storage.

2. Study of the scald berries addition influence on the quality of the fermentation process and the samples storage time investigated by microbiological aspects.

\section{Materials and methods \\ Materials \\ Preparation of fruits pulp}

The fruit puree was obtained according to the following manufacture stages: sorting by removing non-conforming fruits and inedible parts, washing by removing all impurities, drying, cutting, heating the pulp of hard fruits, and passing through a sieve to remove inedible parts, mixing until a homogeneous mass, heating at $95-98^{\circ} \mathrm{C}$ for 5 minutes, immediately pouring the fruit puree into sterile containers, cooling the packaged product, storing.

\section{Preparation of fruit yogurt}

To prepare fermented yogurt the goat and cow milk sample was received from the local farm. Before fermentation, the goat's milk was pasteurized at $85^{\circ} \mathrm{C}$ for 10 minutes and cow's milk was pasteurized at $95^{\circ} \mathrm{C}$ for 15 minutes after which it was cooled to the inoculation temperature $42{ }^{\circ} \mathrm{C}$. For the yogurt manufacture the Lyofast YAB 205 starter culture was used for inoculation. Inoculation was done by direct inoculation of the culture in the required 
amount of milk calculated depending on the milk volume. The contents were mixed for 5 minutes with sterile blender for better dispersion of the culture in the medium. In the inoculated milk mixture, the fruit puree was added, then transferred to the fermentation chamber for 6 hours. The end of the coagulation process was determined by the $\mathrm{pH}$ value and coagulum firmness. When the fermentation process was completed, all samples were taken to the refrigerator for storage at a temperature of $4 \pm 2^{\circ} \mathrm{C}$ until the next control measurement.

The yogurt assortment obtained is presented in table 1:

Table 1

Notify the probe

\begin{tabular}{c|c}
$\begin{array}{c}\text { Sample } \\
\text { code }\end{array}$ & Sample description \\
\hline P1 & $50 \%$ goat's milk + 50\% cow's milk, control sample \\
\hline P2 & $45 \%$ goat's milk $+45 \%$ cow's milk $+10 \%$ aronia. \\
\hline P3 & $45 \%$ goat's milk $+45 \%$ cow's milk $+10 \%$ raspberries. \\
\hline P4 & $45 \%$ goat's milk $+45 \%$ cow's milk + 10\% strawberry. \\
\hline $\begin{array}{c}\text { Sample } \\
\text { code }\end{array}$ & Sample description \\
\hline P1 & goat's milk and cow's milk $(50 \%: 50 \%)$, control sample \\
\hline P2 & goat's milk and cow's milk $(45 \%: 45 \%)+10 \%$ aronia. \\
\hline P3 & goat's milk and cow's milk $(45 \%: 45 \%)+10 \%$ raspberries. \\
\hline P4 & goat's milk and cow's milk $(45 \%: 45 \%)+10 \%$ strawberry. \\
\hline
\end{tabular}

\section{Method}

\section{Physico-chemical methods}

Titratable acidity determination consists in the neutralization of acidic substances in milk with $0.1 \mathrm{n} \mathrm{NaOH}(\mathrm{KOH})$ solution and phenolphthalein as indicator [23]. The calculation formula is:

$$
\text { Acidity }\left({ }^{\circ} \mathrm{T}\right)=10 \cdot \mathrm{V}
$$

where: $\mathrm{V}$ - is the volume of $0.1 \mathrm{~N} \mathrm{NaOH}$ used in the titration.

Active acidity determination consists in determining the milk $\mathrm{pH}$ value using glass electrodes [23].

Water activity. To determine the activity of the water was used LabSwift, it is a portable equipment of high precision, designed by Novasin to measure the activity of the product. Novasin combines modern technology, speed and measurement accuracy. With an SD card for data storage [24].

Total dry matter content. Standard method of oven drying at $102 \pm 2^{\circ} \mathrm{C}$ until a constant mass of the dry residue is obtained [25].

Viscosity was determined using the "Brookfield DV - III" rheometer, with indicator no. 04, 250 rotations / min, data were read after 30 seconds of rotations [26].

Ash content was determined by the direct heating method (standard method), [27]. The ash content was calculated according to the formula.

$$
\% \text { Ash }=\frac{Z-X}{Y-X} \times 100
$$


where: $\mathrm{X}=$ weight of the empty crucible;

$Y=$ crucible weight + sample;

$\mathrm{Z}=$ crucible weight + ash.

Determination of the total protein content. The total protein contents of the were measured using the Kjeldahl method [28].

\section{Microbiological methods.}

Growth rate of lactic acid bacteria The methodology is based on the work of Lambert and others [29, 30]. The most common way to assess microbial growth in solution is the measurement of the optical density at $600 \mathrm{~nm}$, or short OD600. The method is described according [31 - 34].

To monitor the development of bacterial cells in the fermentation medium, a colorimetric determination is made on a Heidolf spectrophotometer $(\lambda=600 \mathrm{~mm})$ after prior dilution with distilled water. For this purpose, $1 \mathrm{ml}$ of homogeneous fermentation medium is diluted with $9 \mathrm{ml}$ of distilled water, shaken and the extinction is read on a spectrophotometer in a $1 \mathrm{~cm}$ cuvette from the control represented by distilled water. The optical density is calculated according to the following formula:

$$
D O=A_{600} \times 10,
$$

where: A600 - extinction cited at $600 \mathrm{~nm}$;

10 - sample dilution.

It is noted that during the fermentation process other dilutions may be used, depending on the growth capacity, in order to be able to perform the measurements [32].

Monitoring of growth. The growth of lactobacilli was studied twice by measuring optical density (OD) at $\lambda=600 \mathrm{~nm}$ and $\mathrm{pH}$ value. The method is described according [35] and the formula:

$$
\mu=\frac{\ln X-\ln X_{0}}{\Delta t},
$$

where: $X$ - optical density in the end of the exponential growth phase,

$X_{0}$ - optical density in the beginning of the exponential growth phase,

$\Delta \mathrm{t}-$ the time interval between observations

Determination of lactic acid by titration. The amount of lactic acid was calculated depending on the amount of $\mathrm{NaOH}$ used to determine the acidity, taking into account that $1 \mathrm{ml}$ of $0.1 \mathrm{~N}$ $\mathrm{NaOH}$ corresponds to $0.009008 \mathrm{~g}$ lactic acid [36].

Determination of the total number of microorganisms. The method is described according [37].

Determination of the number of yeasts and molds. AOAC Official Method 2014.05 Enumeration of Yeast and Mold in Food. 2015 AOAC INTERNATIONAL [38].

Determination of lactic acid bacteria using d eManRogosa Sharpe (MRS) agar. The lactic acid bacteria (LAB) in the yogurt were determined using deMan Rogosa Sharpe (MRS) Agar as described by Oxoid Manual [32] and the formula:

$$
C_{f u / m l}=\text { average count } \times \text { diluation factor }(D F),
$$


Statistical analysis. The analysis of the variance of the results was performed by applying the Student test and the version of the Microsoft Office Excel 2010 program. All tests were performed in triplicate. Experimental results are expressed as mean \pm SD.

\section{Results and discussions}

The technology of making yogurt, used in research, is based on the addition of the selected culture, consisting of two lactic acid bacteria: Streptococcus thermophilus and Lactobacillus bulgaricus in a ratio of 1: 1 [39]. The inoculum was used in the form of a mixed culture, which has biotechnological properties corresponding to obtaining a quality yogurt. By using pure culture, a double effect was obtained - technological and hygienic. The technological effect consists in the fact that by the optimal concentration of specific microorganisms in milk the desired acidity and curd for yogurt was obtained. The hygienic effect was manifested by the creation of a favourable microflora dominance over resistant milk contaminants and in the yogurt manufacturing process contaminants.

\section{The evolution of milk fermentation to obtain fruit yogurt}

Milk fermentation is one of the most important phases of the yogurt manufacturing process that depends on creating the right conditions (temperature, time) for the development the specific microflora and plays an essential role in the transformation of milk into yogurt [40]. Lactobacillus bulgaricus has a strong tolerance to oxygen, so the lack of oxygen or the presence of oxygen in small quantities leads to its slow growth. Streptococcus thermophilus, being an active lactic acid producer, quickly performs the fermentation process at the optimum growth temperature $\left(40-42^{\circ} \mathrm{C}\right)$ [41].

During fermentation, the fruit yogurt samples $\mathrm{pH}$ was determined at certain time periods (initially, 2, 4, 6 hours), in order to follow the evolution of the fermentation process. The addition influence of aronia, raspberry and strawberry fruits on the yoghurt fermentation process was evaluated, indicating different $\mathrm{pH}$ values depending on the type of fruit added.

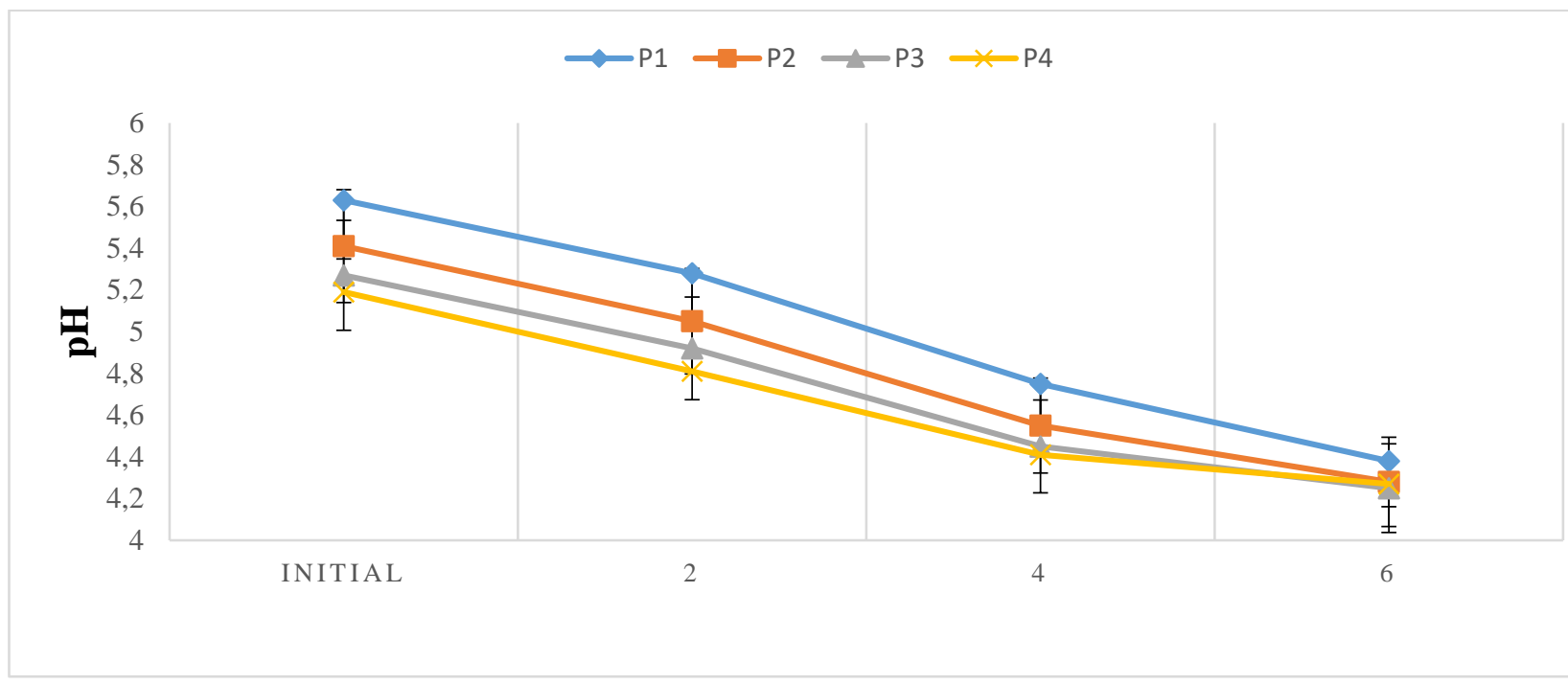

Figure 1. Fermentation time of yogurt samples, h.

From the data presented in figure 1 , a specific dynamics of the microorganisms development according to the growth curve is observed. At the stopping time of the fermentation process, the $\mathrm{pH}$ value indicates results that the process is finished, the number of lactic microorganisms is at the peak of development, because they consume lactose as an 
energy source, and as a result the $\mathrm{pH}$ value decreases. The results obtained for the yogurt samples during fermentation varied in each sample, P2 (5.31 $\pm 0.002-4.28 \pm 0.003)$, P3 $(5.27$ $\pm 0.003-4.25 \pm 0.001)$, and $\mathrm{P} 4(5,19 \pm 0.002-4.27 \pm 0.003)$ relative to $\mathrm{P} 1(5.63 \pm 0.003-$ $4.38 \pm 0.002)$.

Due to its complex chemical composition [42], goat's or cow's milk [43] used in the yogurt manufacture is an excellent environment for the development of many microorganisms, lactic acid bacteria having favorable conditions. Goat's milk compared to cow's milk, in addition to a rich nutritional value, has better antimicrobial properties to pathogenic microorganisms. The antimicrobial properties of goat's milk are exerted by the lactoperoxidase system, which acts as a magnet for iron ions, thus depriving food pathogenic bacteria [44].

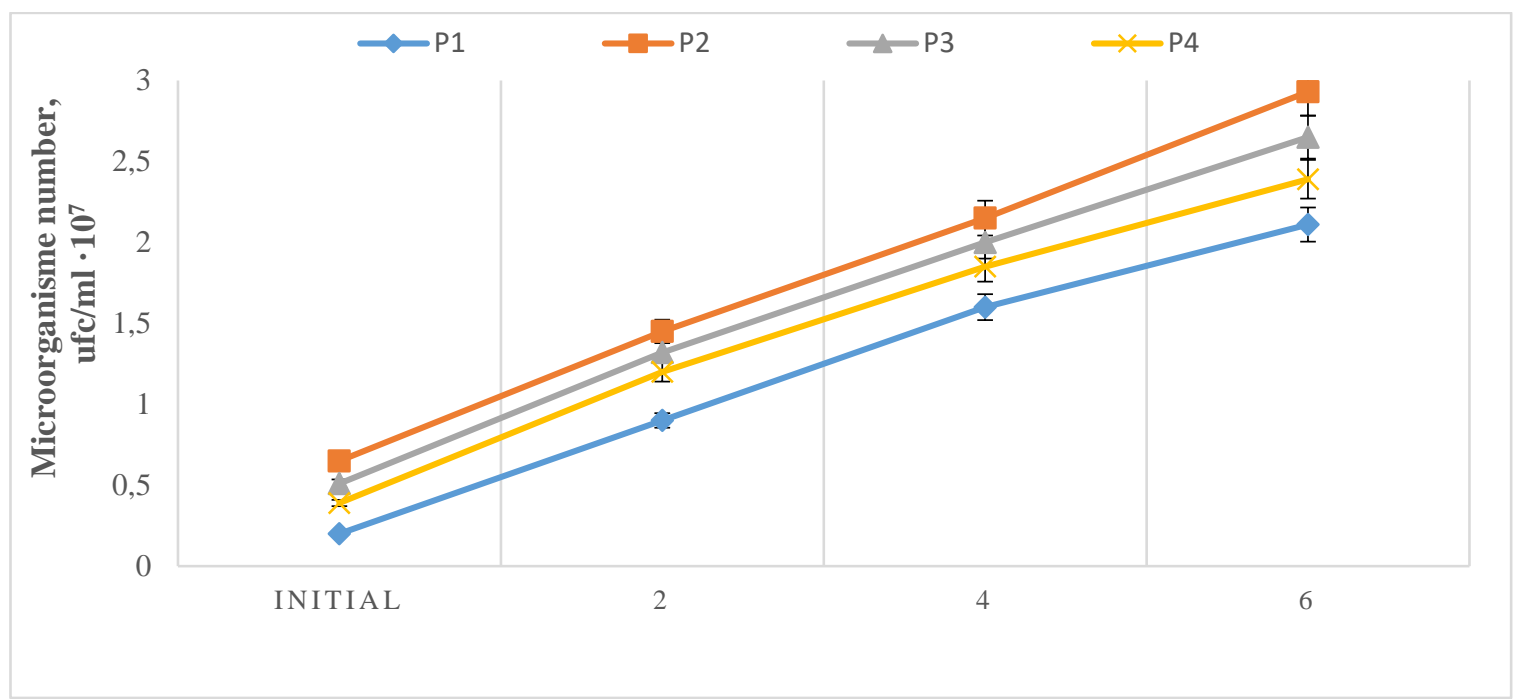

Figure 2. The growth curve of lactic acid bacteria in yogurt.

During fermentation the number of microorganisms increased exponentially and reached a maximum number at 6 hours (figure 2). The results obtained for P2 constitute 0.65 $\cdot 10^{7}-2.93 \cdot 10^{7}$ in relation to the control sample P1-0.20 $\cdot 10^{7}-2.11 \cdot 10^{7}, \mathrm{P} 3$ has values of $0.51 \cdot 10^{7}-2.65 \cdot 10^{7}$, and P4 values of $0.39 \cdot 10^{7}-2.99 \cdot 10^{7}$. These results can be explained by the fact that the production of hydrogen peroxide by Lactobacillus bulgaricus partially damaged Streptococcus thermophilus cells and by the symbiotic relationship of Lactobacillus bulgaricus and Streptococcus thermophilus stimulates the increase in the number of lactic acid bacteria [45].

\section{Accumulation of lactic acid bacteria in fruit yogurt}

The yield of lactic acid production is the main indicator of the starter cultures activity, which is dependent on the biotechnological properties, but also on the physico-chemical and biological conditions [46]. The lactic acid accumulation reduces the ionization of the acidic functions of casein. The caseins average isoelectric point leads to the neutralization of electric charges, the sequestering power of $\alpha_{s}$ and $\beta$ caseins against minerals decreases and the solubilisation of calcium and micellar phosphate takes place [47].

The difference in the lactic acid bacteria growth rate in the researched samples is probably due to the fact that the addition of berries constitutes an improvement of the bacterial growth medium. It was found that, in the control sample, the growth rate of lactic acid bacteria during the fermentation period for $6 \mathrm{~h}$ was P1 $-0.83 \mu$ and for P2 - $0.95 \mu, \mathrm{P} 3-$ $0.93 \mu$, respectively P4 - 0,90 $\mu$. 
Accumulation of lactic acid bacteria in fruit yogurt

\begin{tabular}{|c|c|c|c|c|}
\hline $\begin{array}{c}\text { Fermentation } \\
\text { time / } \\
\text { Evaluated } \\
\text { parameters }\end{array}$ & P1 & P2 & P3 & P4 \\
\hline \multicolumn{5}{|c|}{ Initial (Oh) } \\
\hline $\begin{array}{l}\text { Lactic acid } \\
\text { quantity, } \\
\text { g.dm }{ }^{-3}\end{array}$ & $2.53 \pm 0.02$ & $3.36 \pm 0.02$ & $2.79 \pm 0.03$ & $2.49 \pm 0.02$ \\
\hline $\mathrm{A}_{\mathrm{opt}}, \lambda_{600 \mathrm{~nm}}$ & $0.084 \pm 0.007$ & $0.058 \pm 0.005$ & $0.047 \pm 0.006$ & $0.092 \pm 0.005$ \\
\hline \multicolumn{5}{|c|}{$2 h$} \\
\hline $\begin{array}{l}\text { Lactic acid } \\
\text { quantity, } \\
\text { g.dm }{ }^{-3}\end{array}$ & $14.13 \pm 0.03$ & $16.90 \pm 0.02$ & $15.12 \pm 0.03$ & $14.60 \pm 0.01$ \\
\hline $\mathrm{A}_{\mathrm{opt}}, \lambda_{600 \mathrm{~nm}}$ & $0.161 \pm 0.007$ & $0.215 \pm 0.005$ & $0.175 \pm 0.003$ & $0.136 \pm 0.006$ \\
\hline $\begin{array}{l}\text { Growth } \\
\text { monitoring, } \mu\end{array}$ & 0.21 & 0.35 & 0.29 & 0.30 \\
\hline \multicolumn{5}{|c|}{$4 h$} \\
\hline $\begin{array}{l}\text { Lactic acid } \\
\text { quantity, } \\
\text { g.dm }{ }^{-3}\end{array}$ & $35.15 \pm 0.02$ & $37.56 \pm 0.01$ & $36.85 \pm 0.02$ & $35.86 \pm 0.03$ \\
\hline$A_{o p t}, \lambda_{600 \mathrm{~nm}}$ & $0.450 \pm 0.035$ & $0.821 \pm 0.031$ & $0.758 \pm 0.030$ & $0.652 \pm 0.032$ \\
\hline $\begin{array}{l}\text { Growth } \\
\text { monitoring, } \mu\end{array}$ & 0.51 & 0.78 & 0.76 & 0.72 \\
\hline \multicolumn{5}{|c|}{$6 h$} \\
\hline $\begin{array}{l}\text { Lactic acid } \\
\text { quantity, } \\
\text { g.dm }{ }^{-3}\end{array}$ & $68.18 \pm 0.02$ & $81.56 \pm 0.03$ & $80.94 \pm 0.02$ & $79.64 \pm 0.02$ \\
\hline $\mathrm{A}_{\mathrm{opt}}, \lambda_{600 \mathrm{~nm}}$ & $0.961 \pm 0.025$ & $1.526 \pm 0.028$ & $1.428 \pm 0.030$ & $1.400 \pm 0.026$ \\
\hline $\begin{array}{l}\text { Growth } \\
\text { monitoring, } \mu\end{array}$ & 0.83 & 0.95 & 0.93 & 0.90 \\
\hline
\end{tabular}

This share that lactic acid bacteria growth is due to both: the relevant berries chemical composition and the $\mathrm{pH}$ reduction of the fermentation medium [48, 49].

The Pearson correlation [50] between the $\mathrm{pH}$ and the lactic acid bacteria growth in the fermentation process in the classic yogurt samples and with the berries addition was calculated.

A high correlation was found - close relationship between variables, inversely proportional, because the values were obtained negative.

The results are presented in Table 3 and Figure 3. 
Table 3

Pearson correlation between fruit yogurt fermentation parameters

\begin{tabular}{|c|c|c|c|c|c|c|c|c|}
\hline \multirow{2}{*}{$\begin{array}{c}\text { Fermentatio } \\
\text { n time, } \mathrm{h}\end{array}$} & \multicolumn{2}{|c|}{ P1 } & \multicolumn{2}{|c|}{$\mathrm{P} 2$} & \multicolumn{2}{|c|}{ P3 } & \multicolumn{2}{|c|}{$\mathrm{P} 4$} \\
\hline & $M C \cdot 10^{7}$ & $\mathrm{pH}$ & $M C \cdot 10^{7}$ & $\mathrm{pH}$ & $M C \cdot 10^{7}$ & $\mathrm{pH}$ & $M C \cdot 10^{7}$ & $\mathrm{pH}$ \\
\hline 0 (initial) & 0.2 & 5.63 & 0.65 & 5.41 & 0.51 & 5.27 & 0.39 & 5.19 \\
\hline 2 & 0.9 & 5.28 & 1.45 & 5.05 & 1.2 & 4.92 & 1.2 & 4.81 \\
\hline 4 & 1.6 & 4.75 & 2.15 & 4.55 & 2 & 4.41 & 1.85 & 4.41 \\
\hline 6 & 2.31 & 4.38 & 2.85 & 4.27 & 2.79 & 4.27 & 2.79 & 4.27 \\
\hline $\begin{array}{c}\text { Pearson } \\
\text { coefficient } \\
\mathrm{PC}=\mathrm{f}(\mathrm{pH} \text { and } \\
\mathrm{MC})\end{array}$ & \multicolumn{2}{|c|}{-0.99672} & \multicolumn{2}{|c|}{-0.99436} & \multicolumn{2}{|c|}{-0.9782} & \multicolumn{2}{|c|}{-0.96873} \\
\hline
\end{tabular}

General Pearson coefficient for all fruit yogurt samples

$-0.95066$

\section{${ }^{*}$ Microbial counts $\left(\times 10^{7} \mathrm{CFU} / \mathrm{ml}\right)$}

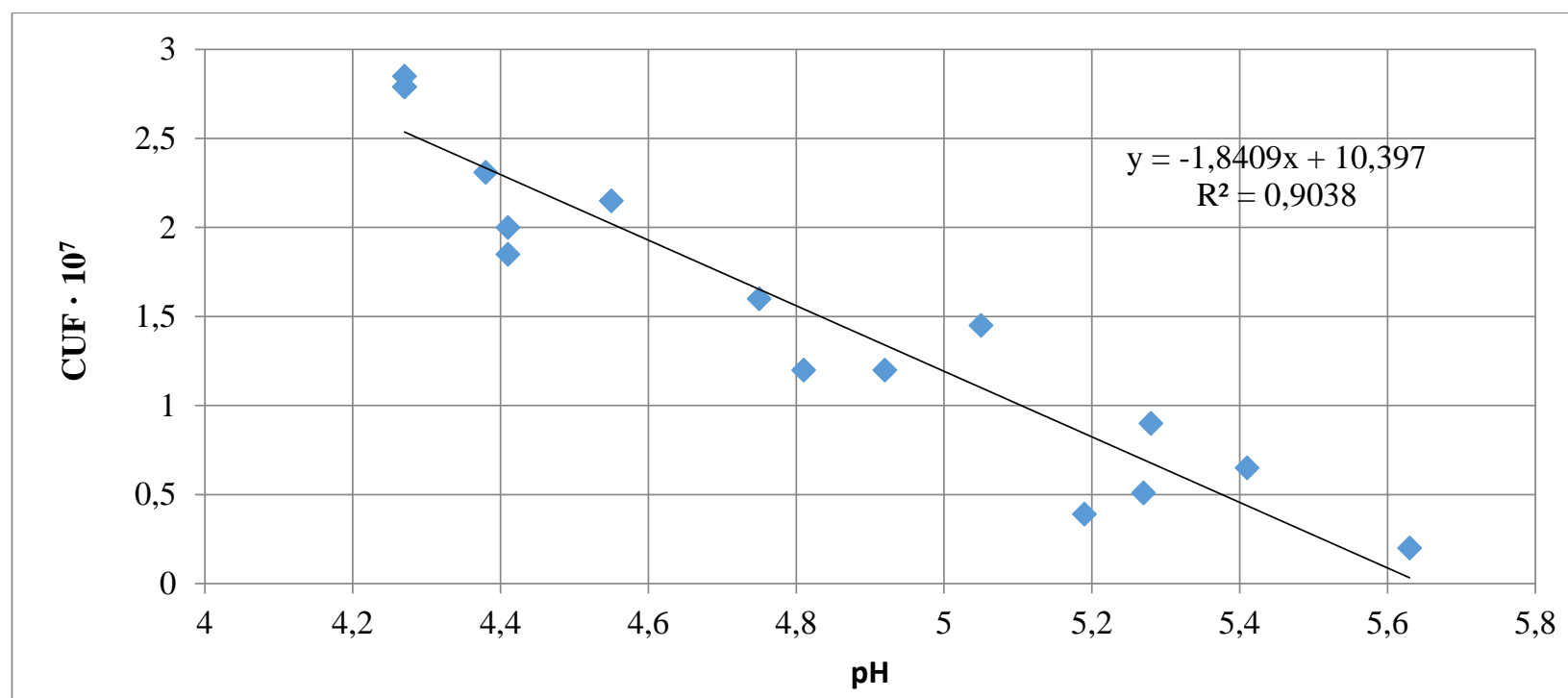

Figure 3. The interdependence between $\mathrm{pH}$ and the lactic acid bacteria number in fruit yogurt.

\section{Analysis of the fruit yogurt physico-chemical indices.}

In this research were studied the fruit yogurt physico-chemical indices. Measuring the yogurt titratable acidity $\left({ }^{\circ} \mathrm{T}\right)$ is a valuable determining practice that must correlate with the additions introduced [51]. The added scald fruits had a great impact on the acidity values. Higher values were obtained for $\mathrm{P} 3-98 \pm 0.082^{\circ} \mathrm{T}$ for $\mathrm{P} 4-91 \pm 0.079^{\circ} \mathrm{T}$ and lower acidity for $\mathrm{P} 2-85 \pm 0.078^{\circ} \mathrm{T}$, as fruits contain more acid than milk, compared to $\mathrm{P} 1-75 \pm 0.080^{\circ} \mathrm{T}$ (control sample). After fermentation, the maximum $\mathrm{pH}$ value was detected in P2 - $4.28 \pm$ 0.002 , this $\mathrm{pH}$ may be caused by the buffering action of higher proteins and minerals present in yogurt. The lower value was obtained for sample P4 - $4.27 \pm 0.003$ and P3 $-4.25 \pm 0.002$, possibly determined by the metabolic activity that persists during refrigeration [52], responsible for this decrease in yogurt $\mathrm{pH}$ values. The $\mathrm{pH}$ of sample $\mathrm{P} 1$ is $4.30 \pm 0.003$ which fits perfectly into the usual $\mathrm{pH}$ range of classic yogurt after fermentation (4.0-4.4). 
The amount of water available to microorganisms is characterized by $a_{w}$. The water activity $\left(a_{w}\right)$ measurement forms the product basis and provides information on the microorganisms growing possibility or on the product. As the water activity value is between 0.8 - 1, then we have a perishable product with a risk of rapid microorganisms development. The water activity differs in each sample, respectively showing the following values: P2 $(0.875 \pm 0.025), P 3(0.873 \pm 0.028)$ and $\mathrm{P} 4(0.872 \pm 0.023)$ compared to P1 $(0.869 \pm 0.021)$. The results obtained are due to the potential acting as a solvent and participating in chemical / biochemical reactions and the microorganisms growth [53].

Table 4

Physico-chemical indices of fruit yogurt

\begin{tabular}{l|c|c|c|c}
\hline \multirow{2}{*}{ Indices } & \multicolumn{4}{|c}{ Yogurt Samples } \\
\cline { 2 - 5 } & $\mathrm{P} 1$ & $\mathrm{P} 2$ & $\mathrm{P} 3$ & $\mathrm{P} 4$ \\
\hline Titrable acidity, ${ }^{\circ} \mathrm{T}$ & $75 \pm 0,080$ & $85 \pm 0,078$ & $98 \pm 0,082$ & $91 \pm 0,079$ \\
\hline $\mathrm{pH}$ & $4.30 \pm 0,003$ & $4.28 \pm 0,002$ & $4.25 \pm 0,002$ & $4.27 \pm 0,03$ \\
\hline $\mathrm{A}_{\mathrm{w}}$ & $0.869 \pm 0,021$ & $0.875 \pm 0,025$ & $0.873 \pm 0,028$ & $0.872 \pm 0,023$ \\
\hline $\begin{array}{l}\text { Total dry matter, } \\
\%\end{array}$ & $17.57 \pm 0,22$ & $18.45 \pm 0,31$ & $18.28 \pm 0,26$ & $18.11 \pm 0,28$ \\
\hline Viscozity, mPa·s & $1250 \pm 0,027$ & $2500 \pm 0,023$ & $1906 \pm 0,022$ & $1829 \pm 0,026$ \\
\hline Ash content, \% & $0.65 \pm 0,12$ & $0.89 \pm 0,10$ & $0.79 \pm 0,12$ & $0.69 \pm 0,10$ \\
\hline Protein content, \% & $3.98 \pm 0.052$ & $3.96 \pm 0.05$ & $3.94 \pm 0.04$ & $3.93 \pm 0,04$ \\
\hline
\end{tabular}

Total dry matter plays a significant role in developing the desired yogurt consistency. There were differences in the total solids content of the yogurt samples. The highest value was recorded in the case of sample P2 $(18.45 \pm 0.31 \%)$. This result indicated that dry matter increased compared to classic yogurt $(17.57 \pm 0.22 \%)$ with the addition of scald aronia fruit, and casein was in the isoelectric state in which the activity of water particles decreased, not affecting the hydrolysis effectiveness [54]. For the sample P3 and P4 were obtained $18.28 \pm$ $0.26 \%$ and $18.11 \pm 0.28 \%$ respectively.

Different technological factors influence the rheological properties of yogurt, such as: heat treatment of milk, incubation temperature, the type of culture used and the cooling process. The structure of yogurt gel is a proteins network formed during acid gelation [55]. The gel formation during the yogurt manufacture occurred due to the unstable casein complex that coagulated easily [56]. The viscosity of all fruit yogurt samples showed satisfactory values. Sample P2 recorded the highest values $2500 \pm 0.023 \mathrm{mPa}$.s, because it has a firmer and well-formed curd than the other samples, due to the higher total dry matter content and the increase of the consistency index, process explained by the ratio of casein fractions to the ratio of casein: serum protein in raw materials. This confirms that the aronia addition contributes more to the whey retention in the gel structure and to the stable gel formation over time as a result of its arrangement in the protein network [57]. As a result of these findings, sample P3 indicates values of $1906 \pm 0.022 \mathrm{mPa} \cdot \mathrm{s}$, sample $\mathrm{P} 4$ values of 1829 $\pm 0.026 \mathrm{mPa} \cdot \mathrm{s}$ compared to values of sample P1 - $1250 \pm 0.027 \mathrm{mPa} \cdot \mathrm{s}$.

Mineral salts have a high nutritional value and have an important influence in the technological processes where the milk coagulation phases take place. The addition of scald aronia, raspberry and strawberry has led to an increase in the yoghurt ash content [58]. The ash content changed in each sample, maximum values were obtained for $\mathrm{P} 2-0.89 \pm 0.10 \%$ and lower values for $\mathrm{P} 3-0.79 \pm 0.12 \%, \mathrm{P} 4-0.69 \pm 0,10 \%$ in relation to $\mathrm{P} 1-0.65 \pm 0.12 \%$. 
Protein [59] plays a key role in the yogurt nutritional and technological value. The values obtained for the protein content in yogurt samples were slightly influenced by the addition of scald fruit (Table 3).

\section{Microbiological indices analysis of fruit yogurt}

Yogurt production raises a large number of questions for microbiological safety technologies: how to prevent contamination with microorganisms, what to do with microorganisms that cannot be eliminated by various processing operations, how to preserve taste, texture and ensure durability of acceptable validity. In most "problematic" cases these are yeasts, fungi, heterofermentative lactobacilli [60].

Yeast [61] and mold [62] are agents of yogurt microbial spoilage. They may be present in yoghurt due to contamination during manufaturing, including added prepared fruit, from packaging materials. Overall, yogurt should contain $10^{7} \mathrm{cfu} / \mathrm{ml}$ of viable bacteria [63].

Table 5

Microbiological indices of fruit yogurt

\begin{tabular}{l|c|c|c|c}
\hline & P1 & P2 & P3 & P4 \\
\hline MC, ufc $/ \mathrm{ml} \cdot 10^{7}$ & $2,11 \pm 0.17$ & $2,93 \pm 0.30$ & $2,65 \pm 0.25$ & $2,39 \pm 0.28$ \\
\hline Yeast, ufc $/ 1 \mathrm{~g}, \max$ & Absent & Absent & Absent & Absent \\
\hline Mold, ufc $/ 1 \mathrm{~g}, \max$ & Absent & Absent & Absent & Absent \\
\hline
\end{tabular}

Previous research [64 - 67], indicates that aronia, raspberry and strawberry have bactericidal and bacteriostatic effects on pathogenic and conditionally pathogenic microorganisms such as: Salmonella, L monocytogenes, E. coli, Klebsiella, Bacillus sp. From the data presented in table 4 it results that the berries form a synergism in the control of the microbiological risk and the stability of the yogurt in storage.

The results of research [68] showed that the combined use of lactic acid bacteria with the berries addition had a synergistic effect, as expected, on the risk posed by Bacillus bacteria in food. Aronia was the most effective natural preservative, from the tested fruits, to prevent the damage of yogurt from cow's and goat's milk by Bacillus.

\section{The effect of storage on the fruit yogurt physico-chemical indices Titratable acidity}

Titratable acidity describes the freshness of the yogurt, especially during storage. Milk acidification leads to the destruction of the internal structure of casein mycelium due to the solubilization of k-casein. During storage, due to the upward fermentation process, the titratable acidity of fruit yogurt increases (figure 4). During the yogurt samples storage, the following data were recorded (minimum and maximum): $75 \pm 0.080-82 \pm 0.085^{\circ} \mathrm{T}$ for $\mathrm{P} 1,85$ $\pm 0.078-92 \pm 0.080^{\circ} \mathrm{T}$ for $\mathrm{P} 2,98 \pm 0.082-105 \pm 0.083^{\circ} \mathrm{T} \mathrm{P} 3$ and $91 \pm 0.079-100 \pm 0.081^{\circ}$ T P4. These results indicate that yogurt is a favorable environment for the lactic acid bacteria development [69]. The aronia, strawberry and raspberry fruits introduced in yogurt have a high acidity, thus leading to an increase in titratable acidity compared to the control sample but maintaining it in the range of permissible values according to [70]. 


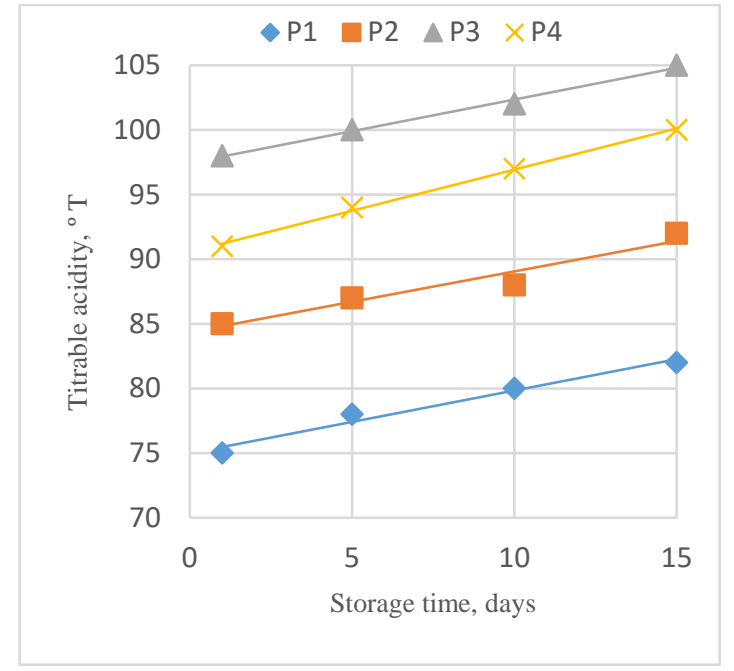

Figure 4. The evolution of the fruit yogurt titratable acidity on stored.

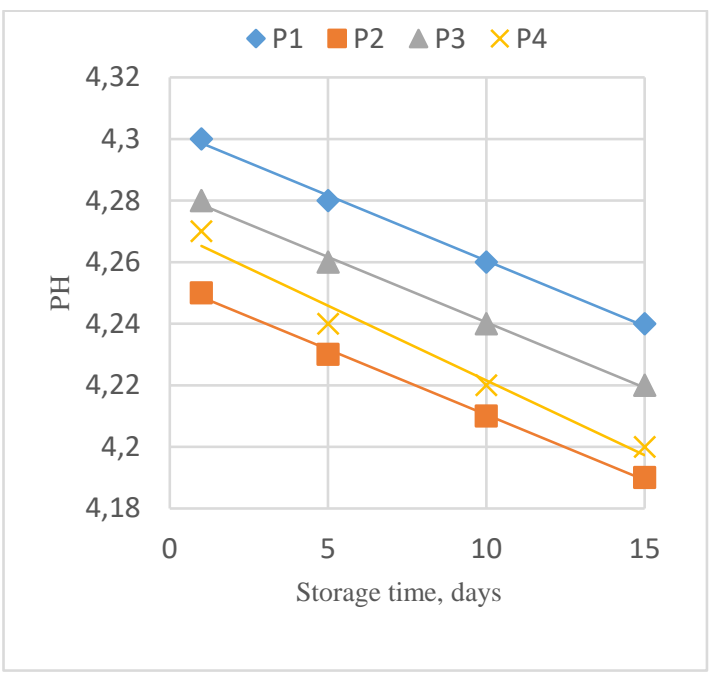

Figure 5. The evolution of the fruit yogurt $\mathrm{pH}$ on stored.

\section{$\mathrm{pH}$}

The role of $\mathrm{pH}$ monitoring in the yogurt manufacture is crucial. $\mathrm{PH}$ measurement is considered a sensitive tool to detect changes in the yogurt active acidity. Some technological stages (heat treatment, fermentation, cooling) have a major influence in the finished product $\mathrm{pH}$ values during storage. Refrigeration temperature is responsible for lowering the fruit yogurt samples pH during storage. Analyzing the results presented in Figure 5, we observe differences in the $\mathrm{pH}$ values of fruit yogurt and the classic one after the first storage day. Initial $\mathrm{pH}$ values in yogurt samples vary, $4.28 \pm 0.002$ for $\mathrm{P} 2,4.27 \pm 0.003$ for $\mathrm{P} 4,4.25 \pm 0.002$ for $\mathrm{P} 3$ front of $4.30 \pm 0.03$ at $\mathrm{P} 1$. The change in $\mathrm{pH}$ during storage showed slightly decreasing values within 1 day $4.28 \pm 0.002$ and on day $154.22 \pm 0.004$ in P2, at sample P3 in 1 day the $\mathrm{pH}$ indicates results of $4.25 \pm 0.002$ and on the 15 th day $4.19 \pm 0.003$, at sample P4 in 1 day the $\mathrm{pH}$ indicates values of $4.27 \pm 0.003$ and at 15 days $4.20 \pm 0.004$ compared to sample P1 with values on 1 day $4.30 \pm 0.002$ and on the 15 th day $4.24 \pm 0.003$. Similar results, decreased $\mathrm{pH}$ values and increased titratable acidity values for yogurt samples during storage were also obtained by [71, 72, 73].

\section{Lactic acid}

In the mixed culture, between the lactic bacteria, cooperation relations are established that positively influence the growth of the other [74]. The production of lactic acid by Lactobacillus bulgaricus is stimulated at low concentrations of formic acid produced by Streptococcus thermophilus in the absence of oxygen and $\mathrm{CO}_{2}$ released by fermentation [75]. Streptococci grow faster and are responsible for acidity while lactobacilli add flavour mainly due to the formation of acetic aldehyde. Through their activity, lactobacilli that have peptidase activity produce nitrogen compounds, assimilable for streptococci, which explains the synergistic relationship between streptococci and lactobacilli in the yogurt manufacture [76].

Optical density $(\lambda, \mathrm{nm})$ is one of the important physico-chemical methods for evaluating the microorganism's growth and development. In the goat's milk nutrient medium [77] all strains are characterized by higher acidification rate - 4.4-7.7 hours, compared to cow's milk medium [78] - 4.6-9.3 hours. 
Table 6

Indicators of fruit yogurt lactic fermentation

\begin{tabular}{|c|c|c|c|c|c|}
\hline $\begin{array}{l}\text { Samp } \\
\text { les } \mathrm{nr} \text {. }\end{array}$ & $\begin{array}{l}\text { Time, } \\
\text { days }\end{array}$ & $\begin{array}{c}\text { Titrable acidity, } \\
\text { oT }\end{array}$ & $\mathrm{pH}$ & Lactic acid, $g$ & $\begin{array}{c}\text { Optical density, } \\
600 \mathrm{~nm}\end{array}$ \\
\hline \multirow{4}{*}{ P 1} & 1 & $75 \pm 0.080$ & $4.30 \pm 0.002$ & $0.02167 \pm 0.025$ & $1.146 \pm 0.058$ \\
\hline & 5 & $78 \pm 0.083$ & $4.28 \pm 0.003$ & $0.02908 \pm 0.026$ & $1.232 \pm 0.055$ \\
\hline & 10 & $80 \pm 0.081$ & $4.26 \pm 0.002$ & $0.03569 \pm 0.023$ & $1.331 \pm 0.052$ \\
\hline & 15 & $82 \pm 0.085$ & $4.24 \pm 0.003$ & $0.04980 \pm 0.027$ & $1.466 \pm 0.053$ \\
\hline \multirow{4}{*}{ P2 } & 1 & $85 \pm 0.078$ & $4.28 \pm 0.002$ & $0.09782 \pm 0.027$ & $2.531 \pm 0.054$ \\
\hline & 5 & $87 \pm 0.081$ & $4.26 \pm 0.004$ & $0.10719 \pm 0.025$ & $2.613 \pm 0.055$ \\
\hline & 10 & $88 \pm 0.083$ & $4.24 \pm 0.003$ & $0.11563 \pm 0.031$ & $2.873 \pm 0.053$ \\
\hline & 15 & $92 \pm 0.080$ & $4.22 \pm 0.004$ & $0.12250 \pm 0.028$ & $2.922 \pm 0.056$ \\
\hline \multirow{4}{*}{ P3 } & 1 & $98 \pm 0.082$ & $4.25 \pm 0.003$ & $0.08855 \pm 0.028$ & $2.241 \pm 0.056$ \\
\hline & 5 & $100 \pm 0.084$ & $4.23 \pm 0.002$ & $0.10599 \pm 0.025$ & $2.519 \pm 0.059$ \\
\hline & 10 & $102 \pm 0.081$ & $4.23 \pm 0.003$ & $0.10989 \pm 0.028$ & $2.765 \pm 0.057$ \\
\hline & 15 & $105 \pm 0.083$ & $4.21 \pm 0.003$ & $0.11512 \pm 0.026$ & $2.868 \pm 0.051$ \\
\hline \multirow{4}{*}{ P4 } & 1 & $91 \pm 0.079$ & $4.27 \pm 0.003$ & $0.06215 \pm 0.028$ & $2.162 \pm 0.058$ \\
\hline & 5 & $94 \pm 0.082$ & $4.24 \pm 0.004$ & $0.07656 \pm 0.029$ & $2.391 \pm 0.053$ \\
\hline & 10 & $97 \pm 0.083$ & $4.22 \pm 0.002$ & $0.09818 \pm 0.025$ & $2.692 \pm 0.055$ \\
\hline & 15 & $100 \pm 0.081$ & $4.20 \pm 0.004$ & $0.10008 \pm 0.026$ & $2.754 \pm 0.055$ \\
\hline
\end{tabular}

According to the data recorded in Table 6, it is observed that the amount of lactic acid increased during the fruit yogurt storage period. The initial values of lactic acid vary in each sample. In the case of sample P2 the value obtained is $0.09782 \pm 0.027$, for sample P3 is $0.08855 \pm 0.028$, for sample P4 $-0.06215 \pm 0.028$, compared to sample P1 $0.02167 \pm 0.025$. The change in lactic acid during the storage period showed slightly decreasing values within first day of $0.09782 \pm 0.027$ and on the 15 th day of $0.12250 \pm 0.028$ in P2, for sample P3 in 1 day lactic acid indicates results of $0.08855 \pm 0.028$ and on the 15 th day of $0.11512 \pm 0.026$, for sample P4 in 1 day lactic acid indicates values of $0.06215 \pm 0.028$ and at 15 days of $40.10008 \pm 0.026$ compared to $P 1$ with values at 1 day of $0.02167 \pm 0.025$ and on the 15 th day of $0.04980 \pm 0.027$. As the number of microorganisms increased, yogurt optical density increased in all samples. For sample P2 the results indicate values increasing at 1 day of $2,531 \pm 0.054 \mathrm{~nm}$ and to the 15 th day of $2.922 \pm 0.056 \mathrm{~nm}$, for P3 -1 day of $2.241 \pm 0.056$ $\mathrm{nm}$ to the 15th of $2.868 \pm 0.051 \mathrm{~nm}$, for P4 - 1 day of 2,162 $\pm 0.058 \mathrm{~nm}$ to a15th day of 2,754 $\pm 0.055 \mathrm{~nm}$, compared to P4 -1 day $1,146 \pm 0.058 \mathrm{~nm}$ to the 15 th day of $1,466 \pm 0.053 \mathrm{~nm}$. The rise in titratable acidity and the decline in $\mathrm{pH}$ was due to the activity of lactic acid bacteria to produce energy [79] through the fermentation process and by breaking the substrate into simpler components. At the same time, the intensive growth of bacteria did not lead to excessive lactic acid accumulation, favorably influenced the physico-chemical parameters of yogurt [80].

\section{The effect of storage on the fruit yogurt microbiological quality}

In the manufacture of yogurt, it is very important to facilitate the survival of the initial bacteria [81]. The viability of beneficial bacteria depends on the availability of nutrients, the 
presence of growth promoters and / or inhibitors, sugar concentration, oxygen, incubation temperature, fermentation time and storage temperature [82].

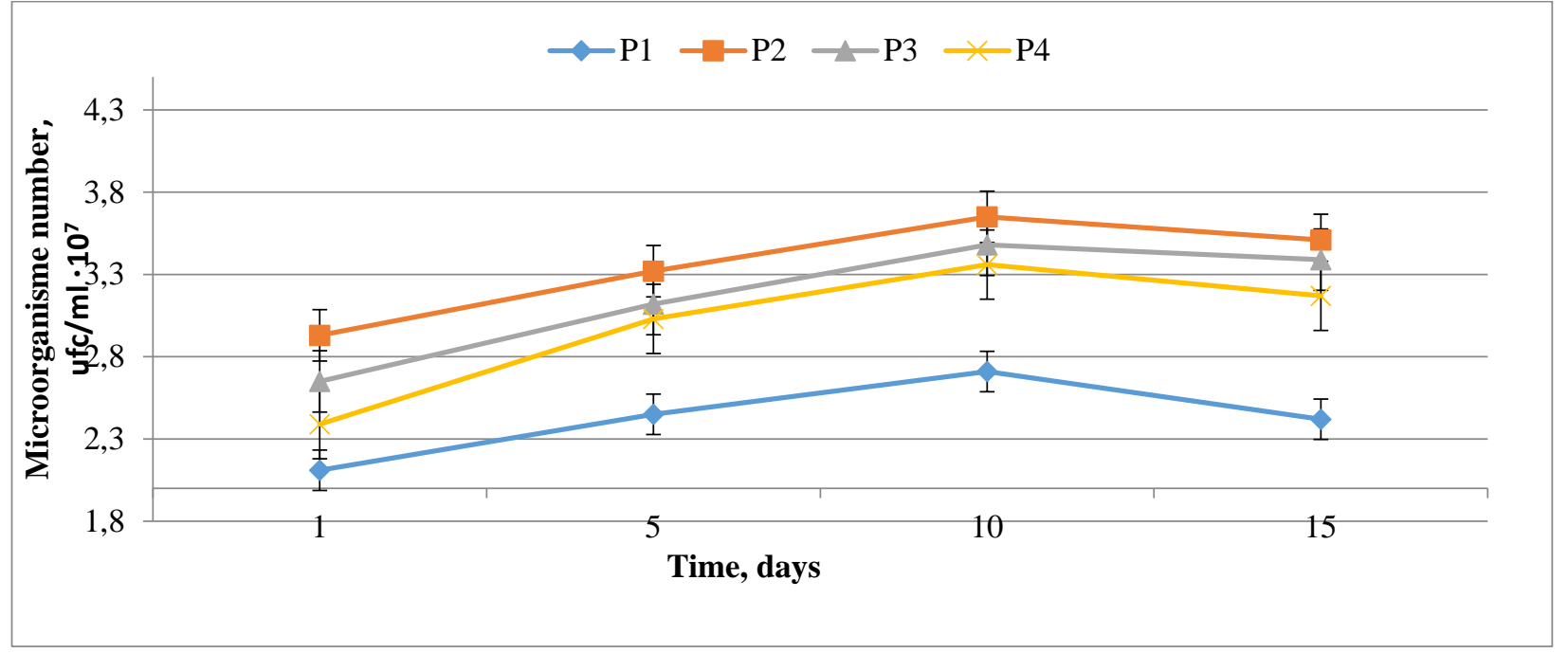

Figure 6. Yogurt lactic bacteria variation in storage.

In a standard environment with fructose or sucrose there is a microorganism's growth inhibition in the mixed culture. Moreover, such an inhibition could be partly due to the osmotic pressure and chemical composition of fruits containing fruit-oligo-saccharide (FOZ) [83].

The results obtained for the variation of fruit yogurt lactic bacteria are satisfactory during the storage period of 1 - 15 days at a temperature of $4^{\circ} \mathrm{C}$ and fall within the values stipulated in the normative documents [84]. During storage the lactic acid bacteria number increased, the values being between $2.93 \cdot 10^{7} \pm 0.30$ and $3.51 \cdot 10^{7} \pm 0.29$ for sample $\mathrm{P} 2$, between $2.65 \cdot 10^{7} \pm 0.30$ and $3.39 \cdot 10^{7} \pm 0.29$ for sample P3, between $2.39 \cdot 10^{7} \pm 0.30$ and $3.17 \cdot 10^{7} \pm 0.29$ for sample P4 compared to sample P1 $2.11 \cdot 10^{7} \pm 0.30$ and $2.42 \cdot 10^{7} \pm 0.29$. Such results suggested that berries have a strong effect by modulating the survival capacity of lactic acid bacteria, when simple sugars such as fructose and glucose were consumed almost entirely during fermentation [85], aronia having the greatest barrier role, in which the loss of lactic acid bacteria was the least reduced.

\section{Conclusion}

Based on the experimental study, it was shown that berries have a relevant composition in biologically active substances, have antimicrobial properties and form a synergism with starter culture in goat's and cow's milk yogurt with scald berries. The incorporation of aronia is highlighted by the best results of physico-chemical and microbiological indices in the initial phase and during storage period, compared to classic yogurt. The average Pearson correlation $(P c=f(p H$ and $M C))$ for the yogurt samples tested was -0.95066 .

Acknowledgments: This work was supported by Moldova State project 20.80009.5107.09 Improvement of food quality and safety by biotechnology and food engineering.

\section{References}

1. Rezac S., Kok C.R., Heermann M., Hutkins R. Fermented foods as a dietary source of live organisms. In: Frontiers in Microbiology, 2018, 9, pp. 1785. 
2. Xiang H., Sun-Waterhouse D., Waterhouse G.I., Cui C., Ruan Z. Fermentation-enabled wellness foods: A fresh perspective. In: Food Science Human Wellness, 2019, 8, pp. 203 - 243.

3. Jesch E.D., Carr T.P. Food ingredients that inhibit cholesterol absorption. In: Preventive Nutrition and Food Science, 2017, 22, pp. 67.

4. Phelan M., Kerins D. The potential role of milk-derived peptides in cardiovascular disease. In: Food and Function, 2011, 2, pp. 153 - 167.

5. Garcia-Burgos M., Moreno-Fernandez J., Alferez M.J., Diaz-Castro J., Lopez-Aliaga I. New perspectives in fermented dairy products and their health relevance. In: Journal of Functional Foods, 2020, 72, pp. 104059.

6. Qian B., Xing M., Cui L., Deng Y., Xu Y., Huang M., Zhang S. Antioxidant, antihypertensive, and immunomodulatory activities of peptide fractions from fermented skim milk with Lactobacillus delbrueckii subsp. bulgaricus LB340. In: Journal of Dairy Research, 2011, 78, pp. 72.

7. Melini F., Melini V., Luziatelli F., Ficca A.G., Ruzzi M. Health-promoting components in fermented foods: An up-to-date systematic review. In: Journal of Nutrients, 2019, 11, pp. 1189.

8. Sanlier N., Gokcen B.B., Sezgin A.C. Health benefits of fermented foods. In: Critical Reviews in Food Science and Nutrition, 2019, 59, pp. 506 - 527.

9. Shiby V.K., Mishra H.N. Fermented milk and milk products as functional foods-A review. In: Critical Reviews in Food Science and Nutrition, 2013, 53, pp. 482 - 496.

10. Hill D., Sugrue I., Arendt E., Hill C., Stanton C., Ross R.P. Recent advances in microbial fermentation for dairy and health. In: F1000Research, 2017, pp. 6.

11. Pappalardo G., Lusk J. The role of beliefs in purchasing process of functional foods. In: Food Quality and Preference, 2016, 53, pp. 151-158.

12.Tamang J.P., Shin D.H., Jung S.J., Chae S.W. Functional properties of microorganisms in fermented foods. In: Frontiers in Microbiology, 2016, 7, pp. 578.

13. Tamang J.P., Cotter P.D., Endo A., Han N.S., Kort R., Liu S.Q., Mayo B., Westerik N., Hutkins R. Fermented foods in a global age: East meets West. In: Comprehensive Reviews in Food Science and Food Safety, 2020, 19, pp. $184-217$.

14. Penas E., Martinez-Villaluenga C., Frias J. Sauerkraut. Production, composition, and health benefits. In: Fermented Foods in Health and Disease Prevention, In: Academic Press: Cambridge, MA, USA, 2017, pp. $557-576$.

15. Abdalla O.M., Abdel Nabi Ahmed S.Z. Chemical Composition of Mish "A Traditional Fermented Dairy Product" from Different Plants during Storage. In: Pakistan Journal of Nutrition, 2010, 9, pp. 209 - 212.

16. Routray W., Mishra H., N. Scientific and Technical Aspects of Yogurt Aroma and taste: A Review, 2011, In: Comprehensive Reviews in Food Science and Food Safety, 10, pp. 208 - 220.

17. Nile S.,H., Park S.,W. Edible berries: bioactive components and their effect on human health. In: Journal of Nutrition, 2014, 30, pp. $134-144$.

18. Kulling, S.,E., Rawel, H.,M. Chokeberry (Aronia melanocarpa)-A review on the characteristic components and potential health effects. In: Planta Medica, 2008, 74, pp. 1625 - 1634.

19. Giampieri F., Forbes-Hernandez T.Y., Gasparrini M., Alvarez-Suarez J.M., Afrin S., Bompadre S., Quiles J.L., Mezzetti B., Battino M. Strawberry as a health promoter: In: Food an Function, 2015, 6, pp. 1386 - 1398.

20. Caruso M.C., Galgano F., Tolve R., Pecora M., Tedesco I., Favati F., Condelli N. Nutraceutical properties of wild berry fruits from Southern Italy. In: Journal of Berry Research, 2016, 6, pp. 321 - 332.

21.Valcheva-Kuzmanova, S.V.; Belcheva, A. Current knowledge of Aronia melanocarpa as a medicinal plant. In: Journal of Folia Medica, 2005, 48, pp. 11-17.

22. Wang S.Y., Lin H.-S. Antioxidant activity in fruits and leaves of blackberry, raspberry and strawberry varies with cultivar and developmental stage. In: Journal of Agricultural and Food Chemistry, 2000, 48, pp. $140-146$.

23. ISO/TS 11869|IDF/RM 150:2012 - Fermented milks - Determination of titratable acidity - Potentiometric method

24. Powitz R.W. (2007), Water activity: a New Food Tool. Sanitarin's file

25. Determination of the total solids content (Reference method). SM EN ISO 5534:2004/AC:2017

26. Brookfield DV3T Viscometer Operating Instructions Manual, No. M13-2100-A0415

27. Baraem P., Ismail Food Analysis Laboratory Manual. Determination of ash content. Editor: Springer International Publishing, 2017.

28. Association of Official Analytical Chemists. Official Methods of Analysis, Washington, DC, USA. In: 18 th edition, 2006.

29. Graph Pad Software Inc. Graph Pad Prism 4.00 for Windows. San Diego, California, 2006. 
30. Lambert RJW, Pearson J. Susceptibility testing: accurate and reproducible minimum inhibitory concentration (MIC) and noninhibitory concentration (NIC) values. In: Journal of Applied Microbiology. 2000, 88, pp. $784-790$.

31. Keiran S., et al. General calibration of microbial growth in microplate, 2016, Readers Scientific Reports, 6, nr. 38828

32. Sandulachi E., Bulgaru V. Microbiologia industrială. Îndrumar metodic. [Industrial microbiology. Methodical guidance]. Editura Tehnica-UTM, Chișinău. 2019, 68p.

33. Alan D. Welman,Ian S. Maddox, 2003, Exopolysaccharides from lactic acid bacteria: perspectives and challenges, In: TRENDS in Biotechnology, 21, pp. 269 - 274.

34. American Public Health Association, Standard Methods for the Examination of Dairy Products, 1978, 14th Ed., Washington D.C.

35. Kask S., Adamberg K., Orłowski A., Vogensen F.K., Møller P.L., Ardö Y., Paalme T. In: Food Research International, 2003, 36, pp. 1037 - 1046.

36. Guzun V. Tehnologia laptelui și a produselor lactate. Lucrări de laborator și practice. [Milk and dairy technology. Laboratory and practical work]. Editura CIVITAS, Chișinău, 2010.

37. SM EN ISO 4833-2:2014/AC:2017 Microbiology of the food chain. Horizontal method for the enumeration of microorganisms.

38. AOAC Official Method 2014.05 Enumeration of Yeast and Mold in Food. 2015 AOAC INTERNATIONAL.

39. Hassan, A., Amjad, I. Nutritional evaluation of yoghurt prepared by different starter cultures and their physiochemical analysis during storage. In: African Journal of Biotechnology, 2010, 9, pp.2913-2917.

40. Vieco-Saiz N., Belguesmia Y., Raspoet R., Auclair E., Gancel F., Kempf I., Drider D. Benefits and inputs from lactic acid bacteria and their bacteriocins as alternatives to antibiotic growth promoters during food-animal production. In: Frontiers in Microbiology, 2019, 10, pp. 57.

41. Mastanjevic K., Kovacevic D., Frece J., Markov K., Pleadin J. The effect of autochthonous starter culture, sugars, and temperature on the fermentation of Slavonian Kulen. In: Food Technology and Biotechnology, 2017, 55, pp. $67-76$.

42. Mehta B.M. Chemical composition of milk and milk products. In: Handbook of Food Chemistry, 2015, pp. $511-553$.

43. Kücükcetin, A., M. Demir, A. Asci, E. M. Comak. Graininess and roughness of stirred yogurt made with goat's, cow's or a mixture of goat's and cow's milk. Short communication. In: Journal of Small Ruminant Research, 2011, 96, pp. 173- 177.

44. Essione E. Lactic acid bacteria contribution to gut microbiota complexity: Lights and shadows.In: Frontiers in Cellular and Infection Microbiology, 2012, 2, pp. 86.

45. Vukotic G., Strahinic I., Begovic J., Lukic J., Kojic M., Fira D. Survey on proteolytic activity and diversity of proteinase genes in mesophilic lactobacilli. In: Journal of Microbiology, 2016, 85, pp. 33-41.

46. Bintsis T. Lactic acid bacteria as starter cultures: An update in their metabolism and genetics. In: AIMS Microbiology, 2018, 4, pp. 665.

47.Juturu V., Wu., J.C. Microbial production of lactic acid: The latest development. In: Critical Reviews in Biotechnology, 2016, 36, pp. 967-977.

48. Sandulachi E. Окислительно-восстановительные свойства клубники и малины, LAMBERT. [Redox properties of strawberries and raspberries], Academic Publishing, SIA Omni Scriptum Publishing, Latvia, 2018, p.109.

49. Ghendov-Moșanu A. Compuși biologic activi de origine horticolă pentru alimente funcționale. [Biologically active compounds of horticultural origin for functional foods] Editura Tehnica- UTM, Chișinău, 2018.

50. Immink, K. Schouhamer, Weber, J. Minimum Pearson distance detection for multilevel channels with gain and / or offset mismatch. In: IEEE Transactions on Information Theory, 2010, 60(10), pp. 5966 - 5974.

51. Bennama R., et al. Effect of fermentation conditions (culture media and incubation temperature) on exopolysaccharide production by Streptococcus thermophilus BN1. In: International Conference on Biology, Environment and Chemistry IPCBEE, 2011, 24, pp. 433 - 437.

52. Degeest B., Mozzi F., De Vuyst L. Effect of medium composition and temperature and pH changes on exopolysaccharide yields and stability during Streptococcus thermophilus LY03 fermentations. In: International Journal of Food Microbiology, 2002, 79, pp. 161 - 174.

53. Sanduachi E. Activitatea apei în produsele alimentare: Monografie. [Water activity in food products: Monografh.] Editura Tehnica-UTM, Chișinău, 2020. 
54. Amatayakul T., F. Sherkat N. P. Shah. Syneresis in Set Yogurt as Affected by EPS Starter Cultures and Levels of Solids. In: Internation Journal of Dairy Technology, 2006, 59, pp. 216 - 221.

55. Sahana N., Yasarb K., Hayaloglu A.A. Physical, chemical and flavour quality of non-fat yogurt as affected by ab-glucan hydrocolloidal composite during storage. In: Food Hydrocolloids, 2008, 22, pp. 1291 - 1297

56. Amal, A., Matter, E., Mahmoud, A. M., Nahla, S., Zidan S. Fruit Flavored Yoghurt: Chemical, Functional and Rheological Properties. In: International Journal of Environmental \& Agriculture Research, 2016, 2(5), pp. $57-66$.

57. Chrubasik C., Li G., Chrubasik S. The clinical effectiveness of chokeberry: A systematic review. In: Phytotherapy Research, 2010, 24, pp. 1107 - 1114.

58. Boghra V.R., Mathur O.N. Physico-chemical status of major milk constituents and mineral at various stages of shrikhand preparation, In: Journal of Food Science Technology, 2000, 37, pp. 111 - 115.

59. Cui J., Dalgleish D., Singh H. Effect of homogenization and heat treatment on the behavior of protein and fat globules during gastric digestion of milk. In: Journal of Dairy Science, 2017, 100, pp. 36 - 47.

60. Papagianni M. Metabolic engineering of lactic acid bacteria for the production of industrially important compounds. In: Computational and Structural Biotechnology Journa, 2012, 3, pp. 8.

61. Lourens-Hattingh A., Viljoen B.C. Growth and survival of a probiotic yeast in dairy products. IN: Food Research International, 2001, 34(9), pp.791-796.

62.Li S., Marquardt R. R., Abramanson D. Immunochemical detection of molds: a review. In: Journal of Food Protection, 2000, 63, pp. 281-291.

63. Hasan M.N., Sultan M.Z., Mar-E-Um M. Significance of fermented food in nutrition and food science. In: Journal of Science Research, 2014, 6, pp. 373-386.

64. Sandulachi E., Cojocari, D., Balan G., Popescu L., Ghendov-Moșanu A., Sturza R. Antimicrobial Effects of Berries on Listeria monocytogenes. In: Journal of Food and Nutrition Sciences, 2020, 11, pp. $873-886$.

65.Sturza R., Sandulachi E., Cojocari D., Balan G., Popescu L., Ghendov-Moșanu A., Antimicrobial properties of berry powders in cream cheese, In: Journal of Engineering Science, 2019, 3, pp. 125 - 136.

66. Bulgaru V., Sandulachi E. Prevenirea alterării produselor lactate acide cu bacterii din genul Bacillus (teze). Conferința Ştiințifico-Practice Naţionale „INOVAȚIA: FACTOR AL DEZVOLTĂRII SOCIAL-ECONOMICE”, Facultatea de Econommie, Inginerie și Știinte Aplicate a Universității de Stat „Bogdan Petriceicu Hasdeu” din Cahul. 2020.

67. Cojocari D., Sandulachi E., Ghendov Moșanu A., Sturza, R. Proprietățile antimicrobiene ale fructelor de pădure metoda standard kirby-bauer disc (teze/rezumat). Conferința Ştiințifico-Practice Naţionale „INOVAȚIA: FACTOR AL DEZVOLTĂRII SOCIAL-ECONOMICE”, Facultatea de Econommie, Inginerie și Știinte Aplicate a Universității de Stat „Bogdan Petriceicu Hasdeu” din Cahul, 2020.

68. Sandulachi E., Bulgaru V., Ghendov-Mosanu A., Sturza R., Controlling the Risk of Bacillus in Food Using Berries, In: Food and Nutrition Sciences, 2021, 12, pp. 557 - 577.

69. Pollard J., Kirk S.F.L., Cade J.E. Factors affecting food choice in relation to fruit and vegetable intake: A review.In: Nutrition Research Reviews, 2002, 15, pp. 373 - 387.

70. Biswas S., Chowdhury A.R. Development of ready to serve beverage with the inclusion of herbal components. In: International Journal of Latest Trends in Engineering and Technology, 2019, 8, pp.147-154.

71. Ochimian I., Grajcowski J., Smolik M. Comparison of some morphological features, quality and chemical content of four cultivars of chokeberry fruits (Aronia melanocarpa). In: Notulae Botanicae Horti Agrobotanici Cluj-Napoca, 2012, 40(1), pp. 253-260.

72. Chee C.P., Gallaher J.., Djordjevic D., Faraji H., McClements D.J., Decker E.A., Hollender R., Peterson D.G., Roberts R.F., Coupland J.N. Chemical and sensory analysis of strawberry-flavoured yogurt supplemented with an algae oil emulsion. In: Journal of Dairy Research, 2005, 72(3), pp. 311 - 316.

73. Karovicova J., Kohajdova Z. Lactic acid fermented vegetable juices. In: Horticular Science, 2003, 30, pp. $152-158$.

74. Mokoena M.P. Lactic acid bacteria and their bacteriocins: Classification, biosynthesis, and applications against uropathogens: A mini-review. In: Journal of Chemistry. Molecules, 2017, 22, pp. 1255.

75. Barrangou R., Alterman E., Hutkins R., Cano R., Klaenhammer. Functional and comparative genomic analyses of an operon involved in fructooligosaccharide utilization by Lactobacillus acidophilus. In: Proceedings of the National Academy of Sciences, 2003, 100, pp. 8957- 8962.

76. De Vrese M., Schrezenmeir J. Probiotics Prebiotics and Synbiotics. In: Advances in Biochemical Engineering/Biotechnology, 2008, 111(1), pp. 66. 
77. Sandulachi E., Bulgaru V. Factor affecting quality of goat's milk yoghurt, In: Advances in Social Sciences Research journal, 2019, 6(2), pp. 205 - 221.

78. Fruscalso V. Influence of the diet allowance, parity and lactation stadium on the physical-chemical and microbiological properties of the bovine milk and the occurrence of unstable not acid milk. Master's Dissertation, 2007.

79. Chammas G. I., Saliba R., Corrieu G., Béal, C. Characterisation of lactic acid bacteria isolated from fermented milk "laban". In: International Journal of Food Microbiology, 2006, 10, pp. 52 - 61.

80. Shah N. P. Probiotic bacteria: Selective enumeration and survival in dairy foods. In: Journal of Dairy Science, 2000, 83, pp. 894 - 907.

81. Aleksandrzak-Piekarczyk T., Mayo B., Fernandez M., Kowalczyk M., Alvarez-Martin P., Bardowski J. Updates in the Metabolism of Lactic Acid Bacteria. In:Biotechnology of Lactic Acid Bacteria: Novel Applications, 2015, 3, pp. 33.

82. Endo A., Dicks L.M.T. Physiology of the LAB In: Lactic Acid Bacteria: Biodiversity and Taxonomy, 2014, pp. $13-30$.

83. Neves A.R., Pool W.A., Kok J., Kuipers O.P., Santos H. Overview on Sugar Metabolism and Its Control in Lactococcus lactis - the Input from in Vivo NMR. In: FEMS Microbiology Review, 2005, 29, pp. 531 - 554.

84. GD No. 158 of 07-03-2019, Regarding the approval of the Quality Requirements for Milk and Dairy Products. Official Gazette No. 111 - 118 art. 218, Annex 4, [in Romanian].

85. Barat A., Ozcan T. Growth of probiotic bacteria and characteristics of fermented milk containing fruit matrices. In: International Journal of Dairy Technology, 2018, 71, pp. 120 - 129. 